Using an ESP program based on Dictogloss Strategy for Developing Tourism and Hotels Students' Listening Skills

\title{
Using an ESP program based on Dictogloss Strategy for Developing Tourism and Hotels Students' Listening Skills
}

\author{
Submitted by \\ Nagwa Abdulrhman Abdulnaeim
}

English instructor for the

Egyptian Tourism Federation

Supervised by

\begin{tabular}{|c|c|}
\hline Prof. Ahmed Hassan Seif Eldin & Dr. Haggag Mohamed Hagga \\
\hline $\begin{array}{c}\text { Professor of curricula and TEFL } \\
\text { Methodology Faculty of } \\
\begin{array}{c}\text { Education } \\
\text { Monofiya University }\end{array}\end{array}$ & $\begin{array}{c}\text { Assistant Professor of Curricula } \\
\text { and TEFL Methodology } \\
\text { Hurghada Faculty of Education } \\
\text { South Valley University }\end{array}$ \\
\hline \multicolumn{2}{|c|}{2021} \\
\hline
\end{tabular}


مجلة العلوم التربوية ـ كلية التربية بالغردقة - جامعة جنوب الوادى

\section{Using an ESP program based on Dictogloss Strategy \\ for Developing Tourism and Hotels \\ Students' Listening Skills}

\section{Abstract}

The present research aimed at investigating the effect of using an ESP program based on Dictogloss strategy for developing Tourism and Hotels students' listening skills. Participants of the research were $(\mathrm{N}=30)$ of Tourism and Hotel students enrolled for the third year in the faculty of Tourism and Hotels, South Valley University, Luxor. The research used the one group quasiexperimental design and the data required were collected through a needs analysis questionnaire, Listening checklist and a pre-post test of listening skills to evaluate the effect of using an ESP program based on Dictogloss strategy on tourism and Hotels students' listening skills. The statistical devices used for that research were t-test, alfa Cronbach formula, person Correlation and Eta Squared. Results revealed that Tourism and Hotels students achieved a significant development in listening skills. Thus, using dictogloss strategy proved to be effective to develop listening skills.

\section{Keywords: dictogloss, Listening skills, tourism and hotels students}




\section{Using an ESP program based on Dictogloss Strategy for Developing \\ Tourism and Hotels Students' Listening Skills}

\section{برنامج فى اللغة الإنجليزية للأغراض الخاصة قائم على المسرد الأملائى لتنمية مهارات الاستماع لاى طلاب السياحة والقنادق}

المستخلص

هدفت الدراسة الحالية إلى التحقق من تأثثير استخدام برنامج في اللغه الأنجليزيه

للأغر اض الخاصه قائم علي المسرد الأملائي لتطوير مهار ات الاستماع لاى طلاب السياحة و الفنادق. المشاركون في الدراسة (N = 30) من طلبة السياحة و الفنادق المقيدين بالفرقة الثالثة بكلية السياحة و الفنادق جامعة جنوب الو ادي بالأقصر. استخدمت الدر اسة التصميم شبه التجريبي ذو المجموعة الواحدة بقساسيها القبلي والبعدي .ونم جمع البيانات المطلوبة من خلال استبيان تحليل الاحتياجات وقائمة لمهارات الأستماع واختبار قبلي وبعدي لمهارات الاستماع وذللك لتقييم تأثثر استخدام برنامج في اللغه الأنجليزيه للأغراض الخاصه قائم علي المسرد الأملائي لتطوير مهار ات الاستماع لدى طلاب السياحة و الفنادق. تم تحليل النتائج بأستخدام الأساليب الإحصائية التاليه:اختبار t ، معادلة ألفا كرونباخ ، ارتباط الثخص و مربع إينا. أظهرت النتائج أن طلاب السياحة والفنادق حققو اتطوراً كبيراً في مهار ات الاستماع. وبالتالي ، فإن استخدام استراتيجية|لمسرد الأملأئي أثبت فعاليته في تطوير مهار ات الاستماع.

كلمات مفتاحية : المسرد الإملائي - مهار ات الاستماع - طلاب السياحة و الفنادق 


\section{مجلة العلوم التربوية ـ كلية التربية بالغردقة ـ جامعة جنوب الوادى}

\section{Introduction}

The prevalent use of English language as an international means of communication is in constant expansion. This fact is reflected in different fields and in various domains where English is considered as a working tool. As it continues to dominate in business, technology, media, education, medicine, and research, the demand for English for specific purposes (ESP) is rapidly growing to fulfill people with an instrumental purpose (Tsao, 2008; Xu, 2008).Chang (2009) and Tsao (2011) stress that ESP courses are offered to students for meeting their specific needs, as a respond to the significant demand for English in academic and vocational contexts.

English for Specific Purposes (ESP) in addition to General English (GE) are main branches of English as a Foreign Language (EFL) which itself is a main division of English language teaching (ELT). According to the International Teacher Training Organization (2005) "English for Specific Purposes is a term that refers to teaching or studying English for a particular career (like law, medicine) or for business in general". Pauline C. Robinson (1989) describes ESP as a type of ELT (English Language Teaching) and defines it as: "Goal oriented language learning" (Robinson, Pauline C. ed. Hywel Coleman, 1989, p. 398). It means that student has a specific goal that is going to be attained. "English for specific purposes is recommended to the learners who are required to meet the essential, specific and precise needs to respond to the considerable demands in vocational or academic situations in English (Chang, 2009, Tsao, 2011).

Stevens (1988) described ESP as English language teaching that is designed to meet the specified needs of a learner. Students study ESP not only because they are interested in English language but also because they have to perform a task in English. They learn English for a specific purpose, represented by studying subject matter, to gain and develop appropriate knowledge and skills 


\section{Using an ESP program based on Dictogloss Strategy for Developing Tourism and Hotels Students' Listening Skills}

through English. Lorenzo (2005) stated that "ESP students are usually adults who already have some acquaintance with English and are learning the language in order to communicate a set of professional skills and to perform particular job-related functions".

"In ESP the purpose for learning is paramount and related directly to what the learner needs to do in their vocation or job" (Harding, 2007, p. 6). It integrates subject matter and English language instruction. Such a combination is highly motivating because students are able to apply what they learn in their English classes to their major field of study, whether it is computer science, accounting, business management, economics, or tourism.

ESP courses can be distinguished according to the nature of the learners' specialism by three large categories: English for Science and Technology (EST), English for business and Economics (EBE), and English for Social Science (ESS). Designing an ESP course is fundamentally a matter of asking questions in order to provide a reasoned basis for the subsequent process of the syllabus design, material writing, classroom teaching and evaluation. These questions can be considered by three main headings: learning description, theories of learning and needs analysis.Hutchinson and Waters (1987) suggest a classification and definition concerning "needs". They use the terms "necessities", "wants" and "lacks" to explain the word.

Language input is the foundation of language acquisition and listening constitutes the main pillar of that foundation, if listening skills are solidly established, language learners will have better tools to acquire the language more effectively. Harmer (1998) states that listening helps students to acquire language subconsciously even if teachers do not draw attention to its special features.

Listening is the receptive skill in language learning that bridges the productive skills (speaking and writing) as listening is the perception of the information presented which has a significance role in understanding the language and learning how to 


\section{مجلة العلوم التربوية ـ كلية التربية بالغردقة ـ جامعة جنوب الوادى}

speak. Rost (1994) proposed three reasons showing the essential role listening plays to improve speaking skill. "First, spoken language provides a means of interaction for the students. Because students must interact to achieve understanding, access to speakers of the language is essential. Moreover, students ${ }^{e e}$ failure to understand the language they hear is an impetus, not an obstacle, to interaction and learning. Second, authentic spoken language presents a challenge for the student to attempt to understand the language as native speakers actually use it. Third, listening exercises provide teachers with the means for drawing learners attention to new forms (vocabulary, grammar, new interaction patterns) in the language" (p.141-142).

With the increased need to help language learners develop effective listening skills and, "Dictogloss" was introduced by Wajnryb in 1990. In Dictogloss students have opportunities to integrate reading, writing, listening, and speaking skills through social interaction. It is viewed as a classroom dictation activity where learners listen to a passage, note down key words and then work together to create a reconstructed version of the text. The "dictogloss" has been proposed as a procedure that encourages students to reflect on their own output. It is a powerful way of focusing attention on precise meaning, as well as on correct use of grammar. Because it is a cooperative activity, it is challenging without being threatening and it gives learners a chance to discuss language and to learn from each other. Dictogloss activities are practical, yet flexible enough to account for the needs, interests, and learning preferences of each learner. But more than that, the activities allow English learners to be active and reflective during the learning process. 


\section{Using an ESP program based on Dictogloss Strategy for Developing}

Tourism and Hotels Students' Listening Skills

\section{Problem of the Research}

\subsection{Context of the problem}

During the researcher's work as an English instructor for hotel staff, she noticed a lack in the listening skills of some newlyrecruited staff working in hotels. She marked that most of them can hardly understand or process speech when dealing with guests in different communicative situations which consequently lead to a huge misunderstanding and miscommunication when responding to guests' requests, orders and complaints. By asking hotel staff members about their education, the researcher found out that most of them are graduates of Tourism and Hotels faculties, institutes or schools.

To verify the problem the researcher reviewed a few previous studies on tourism English which have dealt with issues such as testing the effectiveness of courses and interventions in developing tourism students' language skills (Hijirida, K.(1980), Fuentes, A. (2004), Haggag, M. (2008), Lo, Y., \& Sheu, C. (2008), Luka, I. (2009), Zayed, J. (2009), and investigating the language needs of students (Afzali, K., \& Fakharzadeh, M. (2009), Choi, K. (2010) and employees (Al-Khatib, M. (2005), Martin, A., \& Davies, S. (2006), Leslie, D., \& Russell, H.( 2006); Tipmontree, S. (2007).

The literature proved that Tourism and Hotels students lack some oral skills among them are the listening skills which can weaken their opportunities to find jobs and hinder their career development. According to Hijirida (1980), knowledge of English is one of the major criteria in hiring people in the tourism field where poor English proficiency becomes a problem in attracting tourists and keeping them satisfied.

To document the problem the researcher pilots a sample of (30) students of the third year's Tourism and Hotels faculty to administrate a questionnaire and a checklist to them. She also interviewed some of their faculty members and ESP instructors. 
مجلة العلوم التربوية ـ كلية التربية بالغردقة - جامعة جنوب الوادى

\subsection{Statement of the problem}

\section{The problem of the research can be stated as follows:}

Many tourism and hotels students lack some listening skills and they are in need of a program to improve these skills. Accordingly, there is a need to construct an ESP program based on dictogloss to develop these skills.

\section{Significance of the Research}

\section{The research thought to be important for the following:}

4.1. Presenting an ESP program based on dictogloss strategy to improve listening skills of Tourism and Hotels' students.

4.2. Implementing an ESP program based on dictogloss strategy that will help in developing Tourism and Hotels students' listening skills.

4.3. It may help in the professional development of Tourism and Hotels students.

4.4. The proposed program can be exploited by hospitality and tourism companies, organizations or entities in staff training, hiring and promotion as it deals with teaching the English language for tourism.

4.5. Enhancing staff's listening skills will lead to a better communication with guests and hence will raise their satisfaction and subsequently it will lead to attract a different category of the guests who may avoid travelling to Egypt because of language barrier.

4.6. Promote students' opportunities to find jobs in the hospitality career after graduation. 


\section{Questions of the Research}

\section{The research seeks to answer the following questions:}

4.1. What is the effect of using an ESP program based on dictogloss strategy in developing listening skills of Tourism and Hotels students?

\section{Objectives of the Research}

\section{The present research aims at:}

6.1. Investigating the effect of an ESP program based on Dictogloss to develop Tourism and Hotels students' listening skills.

6.2. Developing Tourism and Hotels students' Listening skills which considered the most significant skills needed for communication in the hospitality industry.

\section{Hypotheses of the Research}

7.1. There are statistically significant differences between the mean scores of the experimental group in the pre and post tests of the listening skills favoring the post test.

\section{Delimitations of the Research}

\section{The research is delimited to:}

8.1. Participants: Third year students of the faculty of Tourism and Hotels located in Luxor, South Valley University (30 students).

8.2. Listening skills:

- Recognize the communicative functions of utterances, according to situations, participants, and goals.

- Retain chunks of language in short-term memory.

- Process speech at different rates of delivery.

- Listening for gist.

- Listening for note-taking.

- Listening for specific information. 


\section{Review of Literature}

\subsection{English for Specific Purposes}

\subsubsection{Historical Background of ESP}

As a learner-centered approach, English for Specific Purposes (ESP) has become a fruitful field over the last three decades fulfilling the specific needs of target learners to achieve either their professional or vocational demands. Hutchinson and Waters (1987) traced the origins of ESP and listed three main reasons for its emergence. The first was the demand for a brave new world. After the end of the world war II, the enormous expansion in science, technology and economic generated a need for an international language among the different countries. Accepting English language as an international language created a new generation of learners who were learning to keep up with the developments in their fields. For nonnative speakers it was considered the new lingua franca that fulfilled their cross- cultural communication needs, and helped them in making business and sharing information. The second reason was "A revolution in linguistics" where new studies' started to shift from understanding the features of language use to discovering the ways in which language is actually applied in real life communication (Widdowson, 1978).

The final reason Hutchinson and Waters (1987) referred to as an influence for the emergence of ESP was "The focus on a learner" after the educational psychology started to highlight the importance of learners and their attitude towards learning (Rogers,1969) and give more attention to the ways Language can be acquired. Learners were seen to enter with different learning schemata, employ different learning strategies, use different skills, and be motivated by different needs and interests. 
Using an ESP program based on Dictogloss Strategy for Developing

Tourism and Hotels Students' Listening Skills

\subsubsection{English for Specific Purposes Definitions}

There have been multiple attempts to define ESP in language teaching field. Hutchinson and Waters (1987, p. 19) defined ESP as "an approach to language teaching in which all decisions as to content and method are based on the learner's reason for learning". Robinson (1989) describes it as: "Goal-oriented language learning". (Robinson., ed. Coleman, 1989, p 398) that means student has a specific goal that is going to be attained. While Dudley (1998) indicates that ESP as "an attitude of mind can, but not necessarily is concerned with a specific discipline, nor does it have to be aimed at a certain age group or ability range. It employs the underlying methodology and activities of the discipline it serves, centered on the language appropriate to these activities in terms of grammar, lexis, register, study skills, discourse and genre" (p.12).

Robinson (1991, p. 1) described ESP as "an enterprise, which involves education, training and practice, and drawing upon three major realms of knowledge: language, pedagogy and the students' specialist areas of interest". (p.3). Partridge and Starfield (2014), defined ESP as "the teaching and learning of English as a second or foreign language where the goal of the learners is to use English in a particular domain" (p. 2).

English for specific purposes in the present research is operationally defined as "Teaching and learning the language to achieve learners' goals to perform certain job tasks in a particular domain. ESP is taught in integration with the subject matter content of students and show them how the same information is to be expressed in English Language which motivate and reinforce their ability to acquire English Language".

\subsubsection{English for Specific Purposes Characteristics}

In 1988 Strevens provided a definition for English for Specific Purposes by making a distinction between four absolute characteristics and two variable characteristics as follows: 


\section{مجلة العلوم التربوية ـ كلية التربية بالغردقة ـ جامعة جنوب الوادى}

\section{The Absolute characteristics of ESP are}

- Designed to meet specified needs of the learner.

- Related in content to particular disciplines, occupations and activities.

- Centered on language appropriate to those activities in syntax lexis, discourse and semantics; in contrast with General English. (Strevens, 1988, p. 1)

\section{The variable characteristics of ESP are}

- May be restricted as to the learning skills to be learned.

- May not be taught according to any pre-ordained methodology. (Strevens, 1988, p. 1)

\subsection{Dictogloss strategy}

\subsubsection{Background and Definitions of Dictogloss}

Although Dictation has a long history in literacy education, it has been in this traditional form criticized as a rote learning method in which students are passive learners merely make a copy of the text the teacher reads which can be considered a mechanical form of literacy. Ruth Wajnryb (1990) developed a new form to do dictation, known as dictogloss and considered it an alternative method of teaching grammar.

Vasiljevic (2010) defined Dictogloss as a classroom dictation activity where the students listen to the passage, note down keywords, and then work in groups to create a reconstructed text in the form of writing. It differs from the regular dictation because learners are not given enough time to write the targeted text while the teacher is reading it out loud. However, learners do take notes while they listen to the text readout four or more times. Then work in pairs using their notes, the learners try to reconstruct the target text from memory.

According to Cambridge university press (2011), Dictogloss is 
Using an ESP program based on Dictogloss Strategy for Developing Tourism and Hotels Students' Listening Skills

a powerful way of focusing attention on precise meaning, as well as on correct use of grammar. It is challenging without being threatening because it is a cooperative activity, and it gives learners a chance to discuss language and to learn from each other.

It is according to Harrel and Jordan (2006) an exciting strategy because it allows students to deeply explore literally and academic English language. It exposes students to spoken and written English language above the level of everyday spoken English they hear and gives them the opportunity to practice listening and writing more formal English.

According to (Wajnryb 1990) Dictogloss embraced interactive communication through the following stages:

1. Preparation. The first stage includes a warm-up related to the topic or a preliminary speaking or writing exercise. In this stage, the teacher informs learners about what they are expected to do during the activity.

2. Dictation. A story, news report, or other text is presented in English at a normal rate of speed. Learners listen to the dictated text and take notes. The number of times the text is repeated will depend on the educational context; the key is to provide natural input to foster listening comprehension skills.

3. Reconstruction. Students work individually or in groups to construct their own versions of the original text, capturing the essence of the text and generating correct grammar. They reproduce the text in their own words, trying to recall as many sequences and details as possible.

4. Analysis and correction. Most of the student collaboration takes place in this stage. Students assess their own texts first using selfassessment then form groups in order to conduct peer assessments. In this final stage, learners play a more active role, relying on their individual points of strength to cooperate and correct each other. Constructive criticism through peer support and teacher guidance 


\section{مجلة العلوم التربوية ـ كلية التربية بالغردقة - جامعة جنوب الوادى}

helps form relationships that encourage students to cooperate through social interaction.

Dictogloss in this research can be operationally defined as "The untraditional, cooperative form of dictation where students are active participants listen to a text, note take the keywords, work and communicate in groups to construct their version of the text, orally present their texts and analyze and correct their peers. Such emergence of cooperative learning with dictation makes learning process more meaningful and effective".

\subsubsection{Related Studies to Dictogloss}

Dictogloss has been the subject of a considerable number of studies, which have supported the use of it such as, ( Llewyn, 1989; Cheong, 1993; Kowal \& Swain, 1994; Swain \& Miccoli, 1994; Nabei, 1996; Storch, 1998; Swain \& Lapkin, 1998; Lim, 2000; Lim \& Jacobs, 2001a, b; Brown, 2001; Swain, 2001). Among the reasons given for advocating the use of dictogloss are that students are encouraged to focus some of their attention on form and that all four language skills - listening (while listening to the teacher read the text and to groupmates discussing the reconstruction), speaking (speaking with groupmates during the text reconstruction), reading (notes taken while listening to the teacher, the text reconstruction, and the original text ), and writing the reconstruction) - are involved. Further potential benefits of using Dictogloss are discussed later in this paper.

Another study was conducted by Rismayanti (2009) in which the purpose of the study was to explore the potential improvement of the students' listening skill through Dictogloss in eleventh grade of high school in Cianjur. Findings from concluded that dictogloss was effective at increasing students' listening scores. Furthermore, the use of dictogloss was found to be effective to provide better listening ability.

Radwan (2010) experimented a study aimed at Using the dictogloss strategy for developing some EFL listening 
Using an ESP program based on Dictogloss Strategy for Developing

Tourism and Hotels Students' Listening Skills

comprehension skills among secondary school students of $\mathrm{Al}$ Shimaa Secondary School for girls in Benha, Qualubia Governorate. The results revealed a significant difference between the pre-post of listening skills favoring the post test showing a great improvement in the students' listening skills such after implementing dictogloss strategy.

A study conducted by Widiasmara (2012) was limited to find out the effectiveness of using dictogloss to improve students' listening ability only in eleventh grade of Vocational school. The study evidenced that Dictogloss was effective in elevating students' listening scores and provided better listening learning.

Mai (2014). Conducted a study aimed at investigated the effects of using dictogloss on second-year English-majored students at Thang Long University students' listening comprehension. The analysis of the data reveals that dictogloss tasks helps participants have better comprehension of the information heard, and students express positive attitudes towards listening learning with dictogloss activity.

\subsection{Listening Skills}

\subsubsection{Back ground and Definitions of Listening Skills}

Listening is one of the receptive skills. Purdy (1997, p. 8) defined listening as "the active and dynamic process of attending, perceiving, interpreting, remembering, and responding to the expressed (verbal and nonverbal), needs, concerns, and information offered by other human beings". Rost (in Guo, 2008, p.4) defines listening, in its broadest sense, as a process of receiving what the speaker actually says (receptive orientation); constructing and representing meaning (constructive orientation); negotiating this meaning with the speaker and responding to the speaker (collaborative orientation); and, creating meaning through engagement, imagination and empathy (transformative orientation). 


\section{مجلة العلوم التربوية ـ كلية التربية بالغردقة - جامعة جنوب الوادى}

Listening, then, is an active, complex process of interpretation in which listeners matches what they hear with what they already know. Saricoban (1999) pointed out that listening is the ability to identify and understand what others are saying. This involves understanding a speaker's pronunciation or accent, his vocabulary and grammar, and understanding his meaning. Listener should be capable of doing these four things simultaneously.

Byrnes (1984) considers that listening comprehension is a "highly complex problem-solving activity", an idea that is explained as listeners' understanding may be determined by the interest on the subject of the message transmitted by the speaker. Another aspect that may hinder listening comprehension process is the pace of the speech presented .Buch (2001) expresses that listening occurs in real time, with no opportunity for repetition, it means that what is said is heard only once in daily situations, unless the listener asks the speaker to say it again. Thus, the speaker determines the speed of the message; therefore, the listener is most of the times unable to rehear the message. Another difficulty that the listeners may face is the lack of vocabulary and the challenging jargons used in a speech.

Brown \& Yule (1983) also state that not only the speed of the message transmitted brings difficulties for the listener to understand, but also the complex vocabulary that the speaker may use could potentially be unknown for the receptor; in that sense, the background knowledge of the listener becomes a key factor too. Expressions used by the speaker such as gestures and body language, or the mean used to transmit the message, such as videos and pictures can reinforce the understanding of the message when it comes to a better interpretation by the listener. Lund (1991) asserts that even though some terms are not understood, often listeners tend to get the general idea what is heard. 
Using an ESP program based on Dictogloss Strategy for Developing Tourism and Hotels Students' Listening Skills

\section{Method and Procedures}

\subsection{Purpose of the research}

The purpose of the research is to investigate the effect of an ESP program based on dictogloss strategy for developing Tourism and hotels students' Listening skills.

\subsection{Research Design}

The present research followed the quasi-experimental design. pre-post test design treatment group was exposed to pre-post testing. They were taught using the proposed ESP program based on Dictogloss.

\subsection{Variables of the Research}

\subsubsection{Independent Variables}

An ESP program based on Dictogloss.

\subsubsection{Dependent variables}

Listening Skills

\subsection{Materials and Instruments of the Research}

10.4.1. Needs analysis Questionnaire to collect the required information from Tourism and Hotels students in order to identify students' necessities, wants and lacks concerning Listening skills and

10.4.2. Listening checklist to check the validity of the questionnaire and the appropriateness of the skills and items to Tourism and hotels students and to the purpose of the checklist.

10.4.3. Interview administrated to both Tourism and Hotels students and Curricula and TEFL staff as well as ESP instructors to recognize how far the ESP program based on dictogloss is needed for third -year Tourism and Hotels' students.

10.4.4. Listening pre-post test. 


\subsubsection{A proposed ESP program based on Dictogloss}

\subsubsection{Construction of the program}

1. Reviewing previous studies related to designing ESP programs and to Dictogloss strategy activities and application.

2. Determining the aims and objectives of the proposed program and the results of needs analysis questionnaire and the listening check list when choosing the program topics.

3. Determining and describing the content and duration of the proposed program.

4. Writing the framework of the proposed program ESP program based on dictogloss.

5. Having the framework of the program evaluated by a jury of curricula and TEFL staff and ESP instructors.

6. Writing the whole program including the Teachers' guide and the Student book.

7. Evaluating the ESP program based on Dictogloss by the same panel of jury of curricula and TEFL staff and ESP instructors to approve its validity concerning the general form and content and the suitability of its lessons and activities based on dictogloss to Tourism and Hotel students and to the objectives of the research.

\subsubsection{Content of the program}

The ESP program based on dictogloss consisted of five units each unit consists of four integrated lessons. The first unit dealt with the hospitality essentials and characteristics should be available in staff members work in hospitality field such as Appearance and hygiene, attitude and behavior...etc. While the second unit tackled the hospitality, standard procedures followed in the major departments of any hospitality establishment such as procedures followed in guest reservation, in the front desk or in cleaning public areas or rooms. The third unit encompassed the means to achieve professional customer service concerning the fundamentals of 
Using an ESP program based on Dictogloss Strategy for Developing Tourism and Hotels Students' Listening Skills

customer service either face to face or over the phone, the successful communication skills and customer care recovery. The fourth unit discussed food and beverage service in details including the steps of service, the service styles, menus, traditions, the kinds, usage and replacement of cutlery and the kinds, usage and replacement of different items of crockery. The fifth and the last unit focused on the health and safety standards should be followed to prevent guests' legal claims and keep guests' safety concerning food allergens and food illness.

\section{ESP program based on dictogloss evaluation tools and activities:}

The program used both the formative evaluation and summative evaluation during and after each session.

\section{a. Formative Evaluation:}

- A Formative evaluation was used at the end of each lesson to assess student's progress of oral skills.

- One of the assessment tools used to make students involved in learning process and provide the researcher with the needed feedback about students' progress in the listening skills was peer evaluation form

- Another important tool to evaluate students' oral skills during their presentations is the Teacher Observation Scale (TOS).

\section{b. Summative Evaluation:}

Summative evaluation was conducted at the end of each unit using Quizzes and at the end of the experiment by the post testing of the listening skills test to measure the students' progress after the application of the ESP program based on dictogloss strategy. 


\section{مجلة العلوم التربوية ـ كلية التربية بالغردقة ـ جامعة جنوب الوادى}

\subsubsection{The Listening Skills Test}

\subsubsection{Construction of the Listening Skills Test:}

- Reviewing the related literature to Listening skills test design.

- Adopting some of the test materials from English for tourism Purposes courses presented either paper- based courses or online courses.

- Six different questions were integrated in the listening test to measure the six needed listening subskills.

- The test was designed on the basis of the table of specifications

- The Listening test was validated by a jury of curricula and TEFL staff as well as ESP instructor to establish its validity.

\subsubsection{Validity of the Listening Skills Test}

\section{Face and content validity}

- To achieve the face and content validity of the preliminary form of the listening skills test, the test was presented to a panel of jurors. Most of the jury member commented as follows:

- The test is suitable for the students' academic levels.

- The test items were well stated.

- The test was a valuable contribution to the literature.

- Some of them suggested some modifications like adding a complete question to measure the skill "process speech at different rates of delivery'. Finally, they indicated that the Listening test can be considered as a valid instrument to measure the assigned listening sub skills. 
Using an ESP program based on Dictogloss Strategy for Developing Tourism and Hotels Students' Listening Skills

\section{The internal Consistency of the listening skills test were calculated as following:}

Table (3): The internal Consistency of the listening skills test

\begin{tabular}{|c|c|}
\hline Dimensions & $\begin{array}{c}\text { Internal } \\
\text { consistency }\end{array}$ \\
\hline - Listening for note-taking & $* *, V \vee Y$ \\
\hline Retain chunks of language in short-term memory & $* *, 0 \leq r$ \\
\hline -Listening for specific information & $*, \Sigma Y r$ \\
\hline $\begin{array}{l}\text {-Recognize the communicative functions of } \\
\text { utterances, according to situations, participants, and } \\
\text { goals. }\end{array}$ & $* *, 701$ \\
\hline - Listening for gist & $* \cdot, \varepsilon \pi r$ \\
\hline -Process speech at different rates of delivery & $*,, \leqslant \leqslant V$ \\
\hline
\end{tabular}

The calculated correlation value (**) is significant at (0.01) and (*) is significant at (0.05)

\section{Reliability of the listening skills test}

\section{Alpha Cronbach}

To establish the reliability of the test the researcher used Alfa Cronbach's formula. The reliability coefficient was $(\cdot, \vee \wedge)$ and this value have a statistical significance that showed the reliability of the test.

Table (4): Alfa Cronbach's reliability value of the Listening skills test

\begin{tabular}{c|c}
\hline Alfa Cronbach's Value & No. of Items \\
\hline$\cdot, \vee \wedge$ & 6 \\
\hline
\end{tabular}

\section{Test retest}

To establish the reliability of the listening skills test the researcher used test retest by administrating the listening skills test to the students for the first time and after wait for 15 days and then administrate it again. The correlation between students grades in the first application and the second application has been calculated to be (0.91) which is significant at (0.01). 
مجلة العلوم التربوية ـ كلية التربية بالغردقة - جامعة جنوب الوادى

\section{Results and Discussion}

\subsection{Results of the Research}

This part is divided into two main sections. The first section deals with the results of the needs analysis questionnaire while the second part embarks upon the results of the experimental study.

\section{Results of the Needs Analysis Questionnaire}

Students were asked to answer the following three parts of the questionnaire:

As for the current curriculum tourism and hotels students disagreed to the following phrases "The current course delivered has a strong curriculum model(s) that supports students' learning", "The sequence, coherence and integration in the current course are strong", "The course is up to date and sensitive to the changing needs in the hospitality" field", "The current course has space and flexibility to allow new areas of development", "The existing course meets the present and long-term needs of the Faculty and Students which are enlisted in the course specification", "The current course content emphasizes students' listening skills" by the following percentages respectively $(73 \%, 77 \%, 93 \%, 93 \%, 83 \%, 93 \%, 93 \%)$.

Concerning the Educational Learning Needs Students decided that "Listening for specific information" "Listening for gist", "Recognize the communicative functions of utterance according to situations, participants, goals", "Retain chunks of language of different lengths in short term memory", "Process speech at different rate of delivery", and "Listening for note-taking" were the most important skills needed to fulfill their educational learning needs. The following percentages were given to the previously mentioned skills respectively $(77 \%, 83 \%, 89 \%, 90 \%, 93 \%$, ,100\%).

As for the target needs Tourism and hotels' students decided that "Appearance \&Hygiene", "Attitude and Behavior", "Body Language", "Handling Guests' Request", "Confirming, Changing 
Using an ESP program based on Dictogloss Strategy for Developing Tourism and Hotels Students' Listening Skills

and cancelling a reservation", "Guest receiving and farewell", "Check in and check out procedures", "Standardized steps of cleaning a bathroom", "Standardized Steps of cleaning rooms", "Positive customer service", "Being customer focused, "Answering a call, putting on hold, transferring a call and closing a call", "Customer service Recovery", "Communication channels", "Service styles", "Steps of service", "Service traditions", "Kinds of Menus", "Taking restaurant Bookings", "Receiving and seating guests", "Handling Drunk and rude guest", "Taking a food and beverage order", "Cutlery and their usages, placement and replacement", "Crockery their usages, placement and replacement", "Presenting the check/bill", "Upselling service", "Setting the table", "Clearing the table after meal", "Presenting the check/bill", "Understanding food Allergens", "Standard procedure of dealing with a food allergy case", "Food contamination", "Food borne illness", "7 principles of HACCP", "Requirement of food safety", "Legal claims and their effect" "Setting a table for dinner" and "Taking a phone call" were the most important topics that can be applied in their future career. Consequently, the ESP program based on dictogloss was designed focusing mainly on the previously mentioned topics.

The following percentage were given to the previously mentioned topics respectively $(100 \%, 100 \%, 87 \%, 100 \%, 100 \%, 100 \%$, $87 \%, 87 \%, 90 \%, 100 \%, 87 \%, 90 \%, 93,97 \%, 100 \%, 100 \%, 97 \%, 93 \%$, $90 \%, 80 \%, 97 \%, 100 \%, 100 \%, 97 \%, 80 \%, 93 \%, 80 \%, 93 \%, 93 \%, 100 \%$, $93 \%, 100 \%, 90 \%, 93 \%)$.

\section{Results of the Experimental Research}

Hypothesis I predicted that There would be statistically significant differences between the mean scores obtained by participants of the research in the pre and post tests of the listening skills favoring the post test. Statistical analysis showed that this hypothesis was accepted at "t" value (13.71) was significant at (0.01).Table (15) showed the mean scores, $\mathrm{t}$ value, standard 


\section{مجلة العلوم التربوية ـ كلية التربية بالغردقة - جامعة جنوب الوادى}

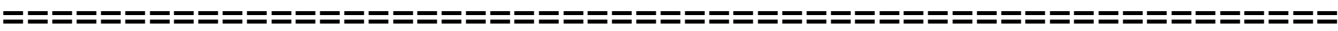
deviation value and Eta square of the pre post test performance of the research group on the listening skills test.

Table(15): Mean, Standard Deviation T-value and Eta-squared of the pre post performance of the research group on the listening skills test.

\begin{tabular}{l|c|c|c|l|l|l|l}
\hline Application & N. & Mean & STD & $\begin{array}{l}\text { T } \\
\text { value }\end{array}$ & $\begin{array}{l}\text { Eta } \\
\text { square }\end{array}$ & Df & Sig \\
\hline Pre test & & 28.7 & 3.31 & & & & \\
\cline { 1 - 3 } Post test & 30 & 33.36 & 3.85 & 13.71 & , ^^7 & 29 & 0.01 \\
\hline
\end{tabular}

The above table showed that was statistically significant differences between the mean scores obtained by the students in the pre post test performance of the listening skills test as " $\mathrm{t}$ " value was significant at (13.7).The effect size of Eta squared was(0.866 )and this value showed the effect of the program on the students listening skills. The following figure showed the research group performance in the pre post testing of the listening skills test.

Figure (13): Research group performance in the pre post testing of the listening skills test.

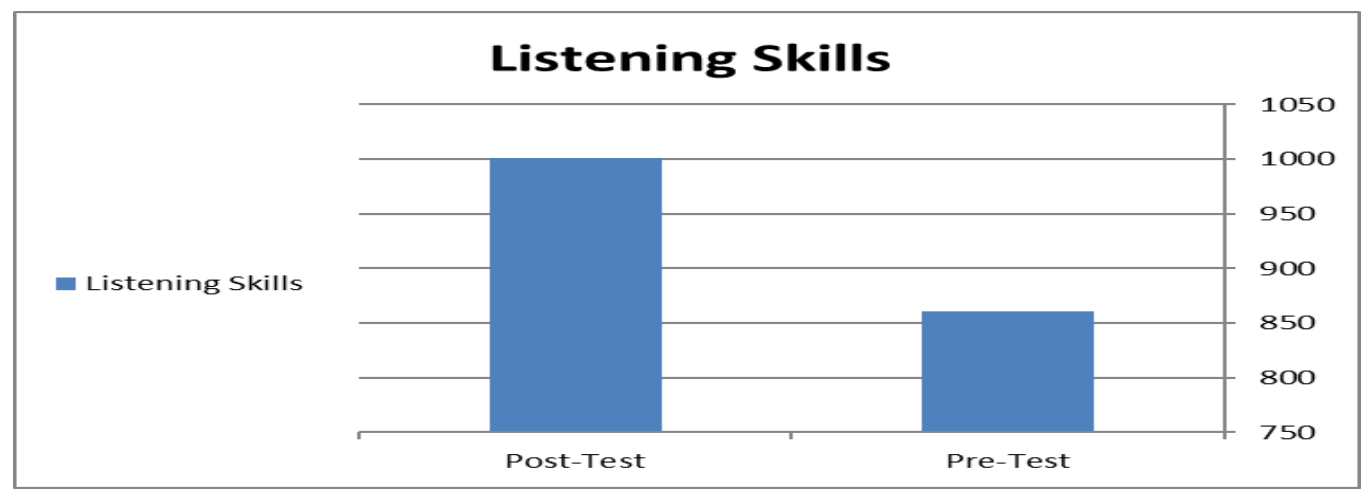

Listening Skills

\begin{tabular}{|c|c}
\hline Pre-Test & Post-Test \\
\hline 861 & 1001 \\
\hline
\end{tabular}


Using an ESP program based on Dictogloss Strategy for Developing Tourism and Hotels Students' Listening Skills

Table (16): Mean, Standard Deviation, T value and Eta-squared of the pre post performance of the Research group on each skill of the listening skills test.

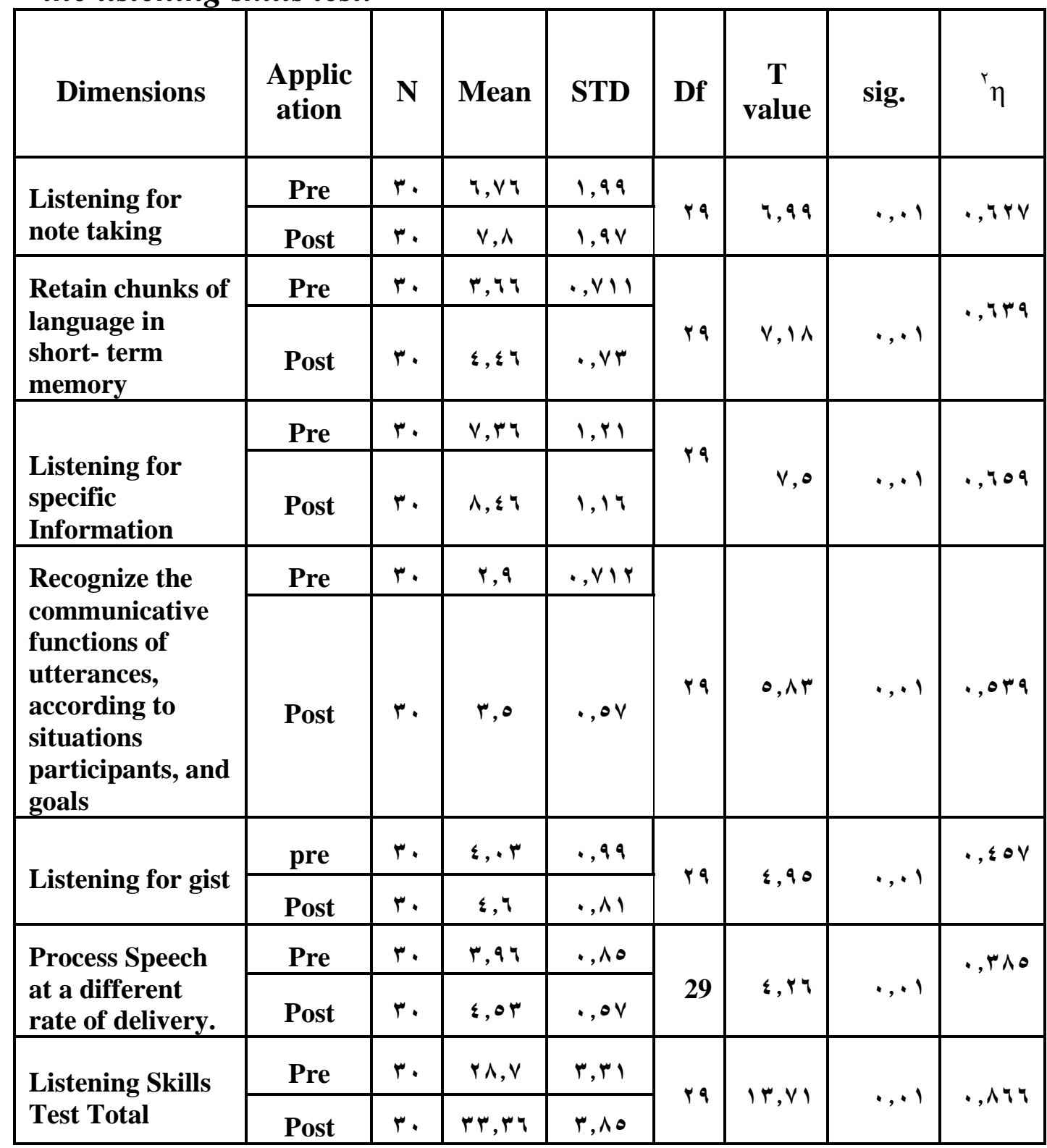




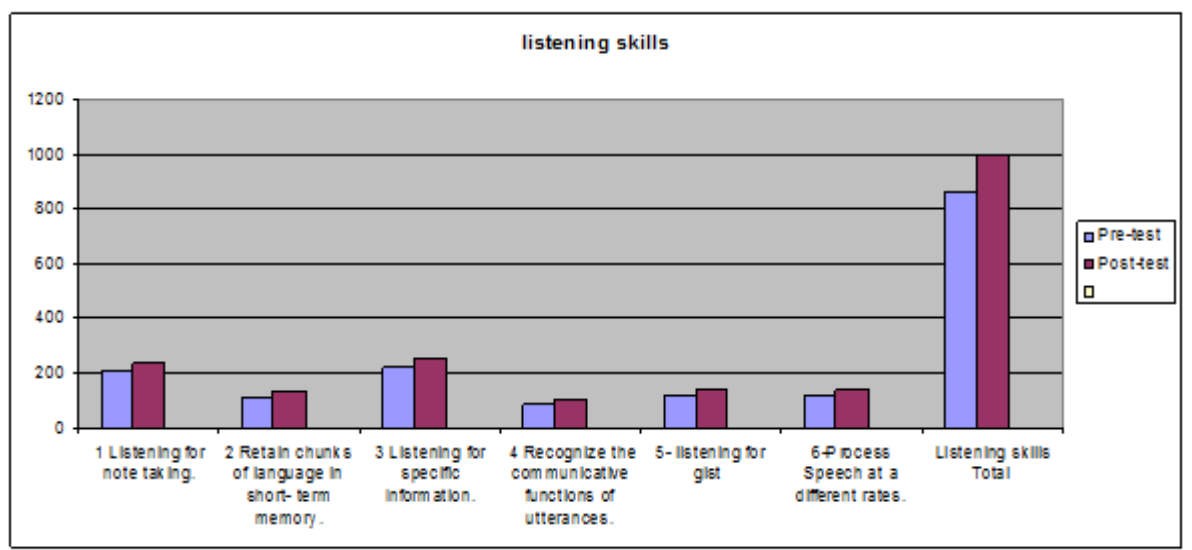

Figure(14):The pre post performance of the research group in each skill of the Listening skills test

\subsection{Discussion:}

Hypothesis I predicted that There would be statistically significant differences between the mean scores obtained by participants of the research in the pre and post tests of the listening skills favoring the post test. Statistical analysis showed that this hypothesis was accepted. Results obtained on the post test of the listening skills test revealed that there was a statistically significant difference. The degree of improvement revealed that students listening skills have been developed using the EPS program based on dictogloss.

The effect size was calculated using Eta Square formula to guarantee that the effect of the ESP program based on dictogloss on listening skills is not due to change.

The ESP program managed to develop Tourism and Hotels students' listening skills by using dictogloss strategy which encourage students to participate aurally during the whole class as well as subject students to a variety of activities that help to develop listening skills such as: True or false, Listening comprehension questions, Matching dialogue with a picture and passage completion. Improving listening through dictogloss happened through the four steps of the strategy. 
Using an ESP program based on Dictogloss Strategy for Developing

Tourism and Hotels Students' Listening Skills

\section{Conclusion, Recommendations and Suggestion for further Research}

\subsection{Conclusion}

Within the limitations of the present research as well as the results reached, the following conclusions could be made:

The research group showed significant development in the listening and it can be concluded that the suggested ESP program based on dictogloss proved to be effective in enhancing these skills.

Before conducting the experiment, it was apparent that most of the students had difficulty in communicating orally. They lacked some oral skills as most of them were either have a difficulty in speech processing and can not fully understand or recall what was being said. Moreover, They had a difficulty in asking and answering questions, responding to requests or taking part in classroom discussions.

However, after being exposed to the suggested ESP program, students of the research group made a significant improvement in listening skills proved by their grade in the pre post test which can be attributed to the use of the proposed ESP program along with the dictogloss strategy which was designed to meet the students' specific needs highlighted by the needs analysis questionnaire, the listening Checklist and the interview.

Dictogloss strategy helped in engaging students in the learning process and making them active participants who listen, speak and communicate either with their peers or with their teacher using the English Language the whole time even in group activities. Learning authentic knowledge related to the hospitality field, a knowledge that they will implement in their further career, raised student selfconfidence and motivation to learning and consequently improved their language skills because learners were encourage to apply what they studied in their jobs. 
مجلة العلوم التربوية ـ كلية التربية بالغردقة - جامعة جنوب الوادى

\subsection{Recommendations}

\section{Based on the results of the present research, the following recommendations were given:}

1. The suggested ESP program based on dictogloss strategy is recommended to be implemented in larger period of at least ten weeks.

2. It is recommended that instructors should dictate the ESP program texts in a regular pace which is not too slow that make students bored and not to fast that hassle, confuse and hinder them during the note taking process.

3. Tourism and Hotels' students should be supported with more English language on- job(Technical) training to enhance their prior knowledge of their future career and reinforce their potentials.

4. Instructors going to teach the ESP course should have a solid back ground information about the terminology, jargon of ETP and the standardized instructional procedures adopted by different hospitality establishments either through experience or through reviewing the pertinent literature.

\subsection{Suggestions for Further Research:}

Within the limitations of the present research as well as the results reached, the following topics are suggested for further research:

1. Investigating the effectiveness of ESP program based on dictogloss and active learning strategies for developing Tourism and Hotels Students' oral skills.

2. Investigating the effectiveness of ESP program based on dictogloss for developing Hotel staff members' oral skills and self-esteem.

3. Investigating the effectiveness of ESP program based on dictogloss for developing Hotel staff members' writing skills. 


\section{References}

Afzali, K. \& Fakharzadeh, M. (2009). A needs analysis survey: The case of tourism letter writing in Iran. ESP World, 8(1),1-10.

Al-Khatib, M. (2005). English in the workplace: An analysis of the communication needs of tourism and banking personnel. Asian EFL Journal, 7(2), 1-20.

Brown, G., \& Yule, G. (1983). Discourse Analysis. Cambridge: Cambridge University Press.

Brown, P. (2001). Interactive dictation. Proceedings of the annual conference of the Japan Association for Language Teaching. Kokura, Japan.

Buch, G. (2001). Assessing listening .Cambridge: Cambridge University press.

Chang, W. (2009). A needs analysis of applying an ESP program for hotel employees. Yu Da Academic Journal, 21, 1-16.

Cheong, C. (1993). The dictogloss procedure as a vehicle of grammatical consciousness-raising: A case study (Unpublished Master's thesis).National University of Singapore,Singapore.

Choi, K. (2010). Needs analysis of students of Tourism English . Proceeding of the 10th -Conference of PAAL of Hanyang Women's University (pp. 57-68).Seoul, Korea. doi.org/10.3727/108354210X12904412050099

Dudley-Evans, T., \& St John, M. (1998). Developments in English for specific purposes: A multi-disciplinary approach. Cambridge: Cambridge University Press.

Fuentes, A. (2004). The use of corpora and IT in evaluating oral task competence for tourism English. CALICO Journal, 22(1), $5-24$. 


\section{مجلة العلوم التربوية ـ كلية التربية بالغردقة ـ جامعة جنوب الوادى}

Haggag, M. (2008). The effectiveness of a content-based program for developing English writing skills and languages proficiency of tourism and hospitality students (Master's thesis). Qena University, Egypt.

Harding, K. (2007). English for Specific Purposes. Oxford: Oxford University Press.

Harmer, J. (1998). How to teach English: An introduction to the practice of English language teaching. Malaysia: Longman

Hijirida, K. (1980). A Japanese cultural and language curriculum for Tourism-oriented students: A prototype (Doctoral dissertation). University of Hawaii, USA.

Hutchinson, T., \& Waters, A. (1987). English for specific purposes. New York: Cambridge University Press.

Kowal, M., \& Swain, M. (1994). Using collaborative language production tasks to promote students' language awareness. Language Awareness, 3, 73-93.

Leslie, D., \& Russell, H. (2006). The importance of foreign language skills in the tourism sector: A comparative study of student perceptions in the UK and continental Europe. Tourism Management, 27(6), 1397-1407 https://doi.org/ 10.1016/j.tourman.2005.12.016

Lim, W. L. (2000). An analysis of students' dyadic interaction on a dictogloss task. (Unpublished Master's thesis). National University of Singapore, SEAMEO Regional Language Centre.

Lim, W., \& Jacobs, G. (2001). An analysis of students' dyadic interaction on a dictogloss task . Retrieved from the ERIC database. (ED 456 649)

Lo, Y., \& Sheu , C. (2008). The design, implementation, and evaluation of English tourguide project.The Asian ESP Journal, 4(2), 79-95. 
Using an ESP program based on Dictogloss Strategy for Developing

Tourism and Hotels Students' Listening Skills

Lorenzo, F. (2005). Teaching English for Specific Purposes (ESP). Retrieved

from

http://www.usingenglish.com/teachers/articles/teachingenglish-for-specific-purposes-sp.html

Luka, I. (2009). Development of students' English for Special Purposes Competence in Tourism studies at tertiary level. ESP World, 8, 4.

Lund, R. J.(1991).A comparison of second language listening and reading comprehension. The modern language journal ,75,196-204.

Mai, L. (2014). THE EFFECTS OF DICTOGLOSS ON THE SECOND YEAR ENGLISH-MAJORED STUDENTS'LISTENING OMPREHENSION: An action research project at Thang Long University(Master's thesis).Hanoi University, vietnam.

Martin, A., \& Davies, S. (2006). An evaluation of the language skills in Scottish hotels. Journal of Hospitality, Leisure, Sport and Tourism Education, 5(1), 4-15.

Nabei, T. (1996). Dictogloss: Is it an effective language learning task?. Working Papers in Educational Linguistics, 12 (1), 59-74.

Paltridge, B., \& Starfield, S. (Eds.). (2014). The handbook of English for specific purposes. John Wiley \& Sons.

Purdy, M. (1997). What is listening?. In M. Purdy, \& D. Borisoff (Eds.), Listening in everyday life: A personal and professional approach (pp. 1-20). Lanham, MD: University Press of America.

Radwan, S.M.(2010). Using the dictogloss strategy for developing some EFL listening comprehension skills among secondary school students. (Master thesis), Banha, faculty of education, Banha University, Egypt 


\section{مجلة العلوم التربوية - كلية التربية بالغردقة - جامعة جنوب الوادى}

ニニニニニニニニニニニニニニニニニニニニニニニニニニニニニニニニニニニニニニニニニニニニニニニニニニニニニニニ

Rismayanti, W. (2009). Using dictogloss technique to improve students' listening ability. Indonesia: Unversitas Pendidikan. Retrieved on March 04, 2012 from: http://repository.upi.edu/skripsiview.php?no_skripsi=833.

Robinson, P. (1989). An overview of English for specific purposes. In H. Coleman (Eds.), Working with language: A multidisciplinary consideration of language use in work contexts, (pp. 395-427). Berlin and New York: Mouton de Gruyter.

Robinson, P. (1991). ESP Today: A Practitioner's Guide. New York: Prentice Hall.

Rogers, C. (1969). Freedom to learn. Columbus, OH: Charles Merrill.

Rost, M. (1994). Introducing Listening. London: Penguin.

Saricoban, A. (1999). The teaching of listening. The Internet TESL Journal, 5 (12), 1-7. http://iteslj.org/Articles/SaricobanListening

Storch, N.(1998).A classroom-based study: Insights from a collaborative reconstruction task. ELT Journal, 52 (4), 291 300 .

Strevens, P. (1988). ESP after twenty years: A re-appraisal. In M. Tickoo (Eds.), ESP: State of the art (pp. 1-13). Singapore: SEAMEO Regional Language Centre.

Swain, M., \& Lapkin, S. (1998). Interaction and second language learning: Two adolescent French immersion students working together. The Modern Language Journal, 82, 320337.

Swain, M. \& Miccoli, L. (1994). Learning in a content-based, collaboratively structured course. The experience of an adult ESL learner. TESL Canada Journal , 12 (1),15-28. 
Using an ESP program based on Dictogloss Strategy for Developing Tourism and Hotels Students' Listening Skills

Swain, M. (2001). Integrating language and content teaching through collaborative tasks. Canadian Modern Language Review, 58(1), 44-63.

Tipmontree, S. (2007). The use and the problems of English and intercultural communication skills of Thai tourist police officers (Doctoral dissertation). University of the Thai Chamber of Commerce,Thailand.

Tsao, C. (2011). English for specific purposes in the EFL context: A survey of student and faculty perceptions. Asian ESP Journal, 7(2), 126-149.

Tsao, C. (2008). English-learning motivation and needs analysis: a case study of technological university students in Taiwan. Paper presented at the Basic Research Conference of Chinese Military Academy on it 84th school anniversary, Fongshang, Taiwan.

Vandergrift, L. (2002). Listening: theory and practice in modern foreign language competence. https://www.llas.ac.uk/resources/gpg/67

Vasiljevic, Z., (2010). Dictogloss as an Interactive Method of Teaching Listening Comprehension to L2 Learners. English Language Teaching, 3(1), 1-12.

Wajnryb, R. (1990). Grammar dictation. Oxford: Oxford university press.

Widdowson, H. (1978).Teaching Language as Communication. Oxford: Oxford University Press.

Widiasmara, W. (2012).Teaching Listening Skill through Dictogloss Technique. Indonesia: Retrieved from http://repository .upi.edu/ skripsiview.php?no skripsi=11169.Wilson, 2003

$\mathrm{Xu}, \mathrm{X}$. (2008). Influence of instrumental motivation on EFL learners in China and its implication on TEFL instructional design. Educational Communications and Technology, University 


\section{مجلة العلوم التربوية - كلية التربية بالغردقة - جامعة جنوب الوادى}

ニニニニニニニニニニニニニニニニニニニニニニニニニニニニニニニニニニニニニニニニニニニニニニニニニニニニニニニ

of Saskatchewan. Retrieved from http://www.usask.ca/ education/ coursework/802papers/xu/index.htm.

Zayed, J. (2009).The effectiveness of reflection in developing students'oracy in English at the faculties of Tourism and hospitality (Doctoral dissertation). Mansoura University, Egypt. 